\title{
Ancient Epistolary Theory in the Byzantine School: Pseudo-Libanios' Manual and its Later Versions
}

\author{
Dmitri A. Chernoglazov \\ St. Petersburg State University, \\ 7-9, Universitetskaya nab., St. Petersburg, 199034, Russian Federation; d.chernoglazov@spbu.ru
}

For citation: Dmitri A.Chernoglazov. Ancient Epistolary Theory in the Byzantine School: PseudoLibanios' Manual and its Later Versions. Philologia Classica 2018, 13(2), 265-275. https://doi.org/ $10.21638 / 11701 /$ spbu20.2018.207

Epistolary Styles of Pseudo-Libanios (PL), a late antique manual on epistolary art, were well known to the Byzantines. The task of this article is to show that PL and its later versions were used in Byzantium as school textbooks, and to characterize their function and place in the curriculum of $\dot{\varepsilon} \gamma \kappa u ́ \kappa \lambda ı \varsigma ~ \pi \alpha ı \delta \varepsilon i \alpha$. The research is concentrated on the Late Byzantine period $\left(13^{\text {th }}-15^{\text {th }}\right.$ cc. $)$. The following texts are analyzed: PL in the original version (PL1); Epistolarium Vaticanum, an anonymous version, known in two manuscripts of the $15^{\text {th }} \mathrm{c}$. (EV); Characteres epistolici XL, a collection of forty model letters, widespread during the Late Byzantine and Ottoman period (Ch40). PL1 was used probably within the grammar course or as a transitional link to the course of rhetoric. This is evidenced by its manuscript tradition. EV was used at the early stage of $\dot{\varepsilon} \gamma \kappa u ́ \kappa \lambda \iota \varsigma, \pi a ı \delta \varepsilon i \alpha$, making part of the grammar course. This is clear from its content - model letters are overtly didactic in nature. The use of EV in school is also evidenced by glosses in the manuscripts. Ch40 was studied at a later stage of the educational process - as a part of the course of rhetoric. Scholia in manuscripts show that the text was analyzed with regard to the methods of rhetorical argumentation. The terminology of scholia originates in the treatise On invention, possibly written by Hermogenes of Tarsus.

Keywords: Epistolography, epistolary theory, rhetorical theory, grammar, educational system, school manuals, Pseudo-Libanios, Characteres epistolici, manuscript tradition.

Was epistolography a school discipline in Byzantium? This question is not an easy one. None of the sources, either official or narrative, explicitly states that the skill of writing letters was in any way trained in school. However, this does not mean a negative answer. In general, little is known about the program of Byzantine schools. We dispose of many sources (letters, memoirs, lives of saints and other different texts) in which the school education of the Byzantines is described in detail, but almost no normative texts have been preserved

(C) St. Petersburg State University, 2018 
in which the school curriculum would be systematically presented. Therefore, despite the abundance of research literature on the Byzantine education system, many questions concerning it still remain unanswered. ${ }^{1}$ One of them is the question of epistolography as a school discipline. However, despite the lack of direct evidence, it can be assumed that writing letters were taught in school - we can even conjecture what textbooks were used for this purpose. In the present paper we'll try to demonstrate that primarily Pseudo-Libanios' Epistolary styles and numerous later versions of this treatise surely served as manuals at different stages of the school curriculum. It should be noted that by the term "school curriculum" we mean here, first of all, $\dot{\varepsilon} \gamma \kappa u ́ \kappa \lambda เ$ grammar, rhetoric and dialectics (as a rule, in this order); the subjects of the quadrivium were also studied, but the evidence about them in the sources is sporadic. Egkyklios paideia can be considered as the Byzantine secondary school, attended by children of approximately 12 to 16 years of age (Koukoulès 1948, 119-121).

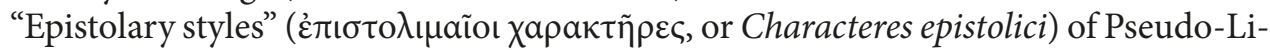
banios/Pseudo-Proklos (further abbrev. PL) is a letter-writing manual, written probably in the $5^{\text {th }} \mathrm{c} .{ }^{2}$ It includes theoretical introduction and samples of letters related to 41 letter types. Widespread in Byzantium, the treatise was numerously copied, commented on, new manuals were created on its base (Chernoglazov 2017). While the treatise itself (in its two original versions) has been well studied, subsequent versions have not been investigated at all, some of them remaining unpublished until today. Among other problems concerning these texts, there remains the question of their functions and use in Byzantium. We will offer an answer to this problem, considering these texts as textbooks for children and collections of school exercises of different levels of complexity. The main attention will be paid to the late Byzantine period - most of our conclusions are based on the study of the manuscript tradition, whereas most of the manuscripts we are interested in are dated back to the $14^{\text {th }}-16^{\text {th }} \mathrm{cc}$., reflecting the use of the treatise during the Late Byzantine and Early Ottoman periods. We will concentrate on three versions of PL, the use of which as educational materials is the most obvious:

1. PL in its original form (further PL1), presented in two main variants - the so called 'Libanios' and 'Proklos' versions.

2. Anonymous later, presumably Late Byzantine version of PL (Epistolarium Vaticanum, further AV), where the introduction and definitions of letters partly go back to PL1, whereas sample letters are entirely independent of it. The text, preserved in two manuscripts of the $15^{\text {th }} \mathrm{c}$., has not been published, but its general description is given in Chernoglazov 2017a.

3. Anonymous collection of 40 sample letters (Characteres epistolici XL, further Ch40), a treatise including examples of 40 types of letters, the list of which almost completely corresponds to PL1. The letters themselves, though going back to the PL1-samples, far exceed them in volume. Ch40, written in the $13^{\text {th }} \mathrm{c}$. and preserved in more than 20 manuscripts, has not yet been published in its complete form. Its critical edition is being prepared by the author of the article.

1 See Koukoulès 1948, 35-137; Lemerle 1971; Kazhdan 1985; Constantinides 1982; Kaldellis, Siniossoglou 2017, 63-78 and review of this survey: Chernoglazov et al. 2018, 4-6.

${ }^{2}$ Ed.: Weichert 1910; Foerster, Richtsteig 1927. English transl. with introduction: Malherbe 1988. Lit.: Sykoutris 1928-1929; Zilliacus 1949, 48-51; Grünbart 2005, 43-46. 


\section{Pseudo-Libanios' "Epistolary styles” (PL1)}

PL1 in both its versions were probably used in the learning process. We are led to this conclusion by the context in which this treatise appears systematically in manuscripts. It's easy to notice that PL1 is often accompanied by treatises that were undoubtedly used as school textbooks. ${ }^{3}$

For example, in Laur. Plut. 57. 34 (15 c.) PL1 is followed by a collection of school manuals on grammar and rhetoric, both ancient and Byzantine: the anonymous treatise On Syntax, Maximos Planudes' Dialogue on Grammar, Pseudo-Herodianus' On Breathings, George Choiroboskos' On Accents, anonymous treatises on dialects and on rhetorical figures, a collection of proverbs. In addition to grammatical and rhetorical treatises, the manuscript contains textbooks on arithmetic, music, geometry and astronomy (Bandini 1961, 387-394). Thus, it is obvious that the manuscript accumulates manuals on almost all subjects of the school curriculum (only dialectics is missing from the trivium), and the fact that PL1 is included in this series suggests that letter writing was one of the disciplines studied.

A similar context can be also found in many other manuscripts. In Palat. gr. 358 (15 c.) PL1 follows a series of grammar manuals, including Manuel Moschopoulos' and Thomas Magistros' Ecloga vocum atticarum, George Lakapenos' The Grammar, anonymous treatises on nouns and verbs and on eight parts of speech; immediately after PL1 an anonymous introduction to Aphthonios' Progymnasmata is copied (Stevenson $1885,208-210)$. Thus, PL is placed as a transitional link between grammatical and rhetorical textbooks. As we are going to see later, it probably corresponds to its position in the educational process. Berol. $g r .308$ (16 c.) is a collection of educational literature. E. g., it contains mythographic treatises (Cornutus' Compendium of Greek Theology and Palaiphatos' On Incredible Tales), an anonymous treatise on prosody and George Choiroboskos' On poetic figures (Studemund, Cohn 1890, 169-170). In Vatop. 527 (15 c.) PL1 precedes an anonymous treatise on grammar. The manuscript also contains various texts of educational content, mostly manuals on grammar: Manuel Moschopoulos' The Grammar,

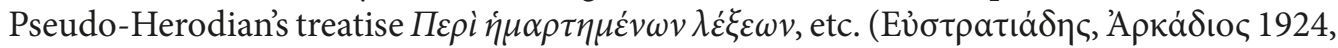
108). Laur. Conv. Suppr. 20 (a. 1341) contains different school manuals on grammar and rhetoric: George Choiroboskos' On poetical figures, Maximos Planoudes' On Syntax, Dialogue on Grammar. PL1 adjoins Michael Psellos' educational poem on the iambic meter (Rostagno, Festa 1893, 138-139). Treatises on grammar and rhetoric can also be found in Paris. gr. 2562 (14/15 c.): Maximos Planoudes' On transitive and intransitive verbs, Dialogue on grammar, On syntax, John Glykas' On syntax of the correct speech, Thomas Magistros' Ecloga vocum atticarum. PL1 continues the collection of Planoudes' manuals (Omont 1886-1888, 3:6).

A series of similar examples could be easy continued: we also dispose of other manuscripts, where PL1 is copied in the context of school manuals, mostly on grammar and rhetoric: Paris. gr. 2881 (Omont 1886-1888, 3:54), Ambr. Q5 sup. (Martini, Bassi 1978, 661-662), Darm. 2773 (Voltz, Crönert 1897), Paris. gr. 1630 (Omont 1886$1888,2: 109-112)$ etc. But let us turn to another question and analyze how PL1 could be used in the curriculum. Its samples of various letter types are certainly too brief and simple to serve as models of real letters, but they could function as a starting point for rhetor-

\footnotetext{
3 About Byzantine school manuals on grammar and rhetoric see: Hunger 1978, 1: 75-91, 2:10-54.
} 
ical development. Perhaps this school practice is reflected in a later edition of PL (further PL2), ${ }^{4}$ which arose, presumably, in the $9^{\text {th }}-10^{\text {th }}$ c.. and contains more extensive samples to all 41 and some other types. In some cases, which are especially interesting for us now, PL2 contains two new samples of the same type, a shorter and longer one - these texts represent different degrees of development of the original. Let us analyze how the sample

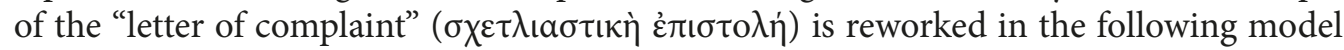
letters of PL2.

PL1, ep. 20 (Weichert 1910, 27. 13-28. 2):

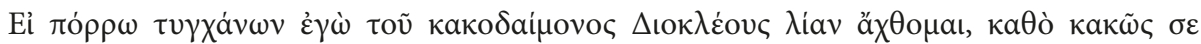

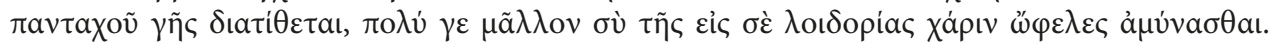

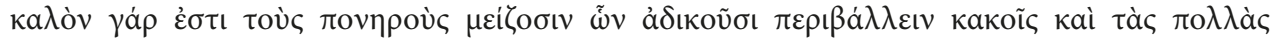

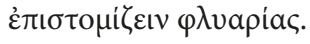

"If even being far from the evil Diocles, I am much grieved to hear the bad rumours he spreads about you all over the world, how much more would you have to punish [him] for blasphemy against you. For it is right to repay bad people more evil for the injustice that they commit, and to prevent the stupid rumours."

\section{PL2, ep. 65 (Weichert 1910, 43. 7-14):}

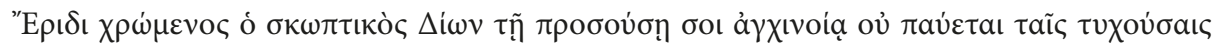

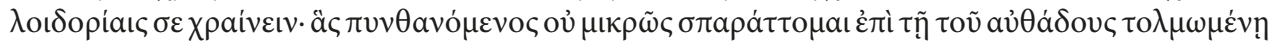

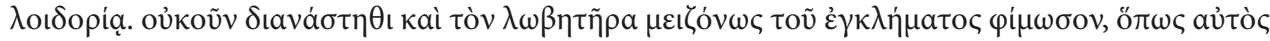

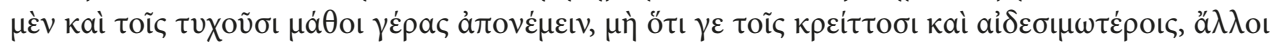

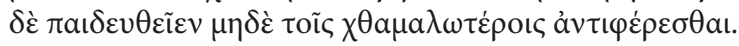

"Harbouring enmity [towards you] because of your intelligence, the mocking Dion does not stop insulting you with whatever bad words he finds. When I hear it, I am greatly distressed by the blasphemy which this insolent dares to utter. Therefore, rise up and muzzle the rascal, repaying him with more [evil] for [his] crime, so that he himself could learn to respect even common people, not to mention the superior and more venerable, and others could learn not to harm even the lower ones."

\section{PL2, ep. 108 (Weichert 1910, 63. 8-21):}

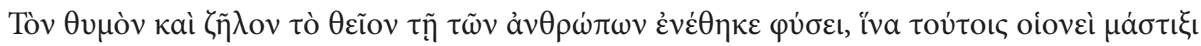

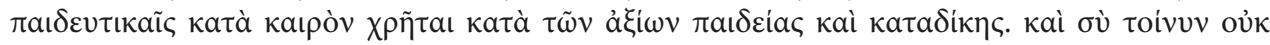

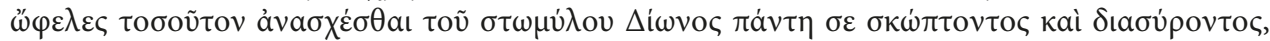

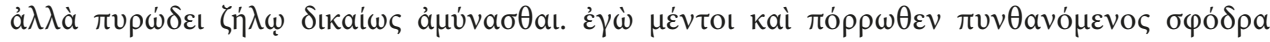

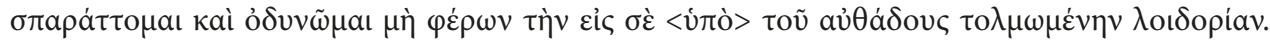

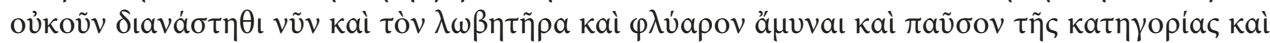

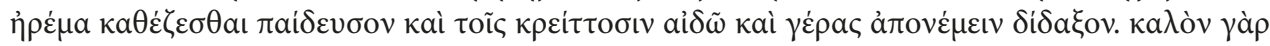

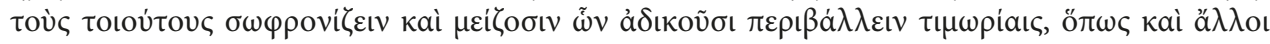

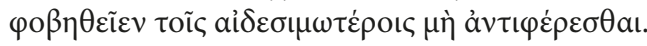

"The Divinity put anger and zeal in the human nature, so that it might use them opportunely as a punishing scourge towards those deserving chastisement and condemnation. So, instead of being so patient when the gossiping Dion mocks and defames you everywhere, you should

${ }^{4}$ Ed. Weichert 1910, 37-66. Lit.: Chernoglazov 2017. 
punish him fairly with ardent zeal. Though hearing of it from afar, I am very distressed and sad, because I cannot bear the blasphemy which this insolent dares to utter. Therefore rise up now, punish the scoundrel and slanderer, stop [his] accusations, teach him to behave quietly and to treat the superior with respect and veneration. For it is right to chasten such people, repaying them with more evil for the injustices that they commit, so that others might be afraid to harm even the lower ones."

It is easy to see that ep. 65 is an extended version of ep. 20, and ep. 108 is the result of the extension of ep. 65. The means of this amplification are not only epithets and periphrastic constructions, but also additional arguments, which here prompt the addressee to punish his opponent. It can be assumed that precisely in this way PL1 was reworked at the Byzantine school: the task of the students might have been to expand them, which meant finding suitable additional arguments that justify the given thesis, and applying the entire arsenal of rhetorical means. Selected results of this school practice may have become a part of PL2, and by comparing three similar texts, we can trace the process of development of the original short sample. Such tasks could be performed at an early stage of the rhetorical course - perhaps as a prelude to studying more complex rhetorical progymnasmata, where the students were trained not in the epistolary style, which was regarded as relatively simple, but in epideictic rhetoric, which required a higher level of skill and knowledge.

However, the samples were used not only as a starting point for rhetorical exercises, but also as material for purely grammatical analysis. It is evidenced by Paris. gr. 1760 (15 c., Omont 1886 - 1888, 2: 136), where the text of the PL1 samples is preserved with mostly grammatical scholia, accompanying some of the samples. ${ }^{5}$ E. g., the following comments are given to the "denying letter":

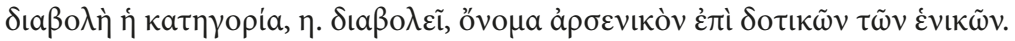

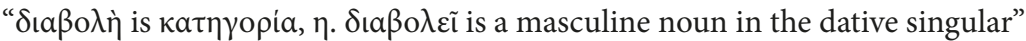

More detailed scholia are added to the "contemptuous letter" (PL, ep.):

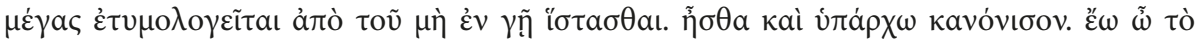

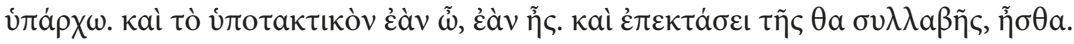

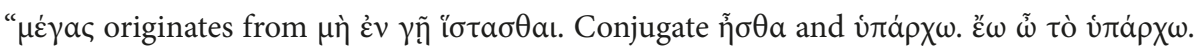
The subjunctive is: $\dot{\varepsilon} \grave{\alpha} v \tilde{\omega}, \hat{\varepsilon} \grave{\alpha} v \tilde{\eta} \zeta$. By lengthening the syllable $\theta \alpha$ [we get] $\tilde{\eta} \sigma \theta \alpha . ”$

Here the comments explain the meaning, origin or grammatical characteristics of some words found in the samples. The same sort of information is given, as a rule, in Byzantine textbooks on grammar, such as the grammatical erotapokriseis of Manuel Moschopulos, which explain the meaning and etymology nouns and adjectives used as examples of declension. ${ }^{6}$ However, some of the notes accompanying PL1 are no longer relevant to the commented text, especially a lot of scattered notes at the end of the treatise, which occupy a whole page of the manuscript. So the letter writing manual grows into a collection of notes similar in content to schoolbooks on grammar.

\footnotetext{
${ }^{5}$ Some of these scholia are published in the apparatus of V. Weichert's edition.
}

${ }^{6}$ E. g. Moschopulus 1540, 24.4-5, 27.3-5, 32.11-14 etc. 


\section{Epistolarium Vaticanum (EV)}

This treatise is even more obviously focused on the school course than its original PL1. This is clearly shown by both the content of the manual and its manuscript tradition. Firstly, the very beginning of EV provides us with valuable information concerning its place in the educational process. The first sentence of the treatise runs as follows:

"For someone who got some knowledge of the logoi and learns the rules of the syntax of the parts of speech, it is proper to exercise also in the movements of his own mind and learn to compose oral speeches. However, the most desirable, really necessary and respectable matter is the art of letter writing."

Learning the "syntax of parts of speech" was included in the grammar course, after which, within the framework of the Byzantine $\dot{\varepsilon} \gamma \kappa u ́ \kappa \lambda \iota \varsigma \varsigma \pi a ı \delta \varepsilon i a$, rhetoric was studied, which implied exactly "exercises of one's own mind," that is, composing short educational speeches, the so called progymnasmata (Hunger 1978, 1:92-120). It can be assumed that this textbook, as well as its prototype PL1, was studied at the final stage of the grammar course, as a transitional link to the rhetoric.

Secondly, the samples, being overtly didactic in tone, were obviously addressed to young people or even schoolchildren. As an example we can cite the model of the "letter of censure":

"It seems to me that you are not one of the good children, you, silly boy, but one of the most unreasonable. You should not have been so curious and try to learn something that is beyond your capacities. Henceforth do not behave like this and inquire into these things. Otherwise it would be better for you to perish."

In other letters the author similarly instructs the addressee in virtue, urging, first of all, to obedience and diligence in learning: the "advising letter" teaches to be sincere, modest and "obey the superior [people]"; the "teaching letter" warns against sleeping too long and eating too much, which "causes a storm in the head", and prompts to prefer "verbal ambrosia" in order "not to appear barren before the Muses"; the "encouraging letter" convinces to learn all the more diligently for all the difficulties such study may entail; the

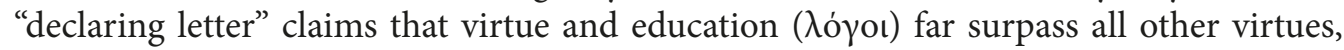
such as strength, beauty or wealth.

Thirdly, many words in both manuscripts of EV (especially in the theoretical part) are provided with synonyms, which are written above them. Let us cite a number of examples from the first sentence of the treatise. In the following pairs of words, the first is contained in the text, and the second is placed above as a synonym: $\mu \varepsilon \theta \varepsilon \dot{\xi} \xi \varepsilon-\mu \varepsilon \tau o x \tilde{\eta} ; \gamma \varepsilon v o$ $\mu \varepsilon v o \varsigma-$

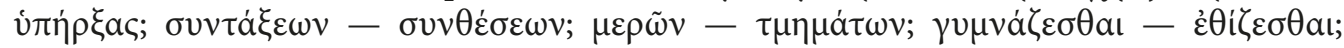

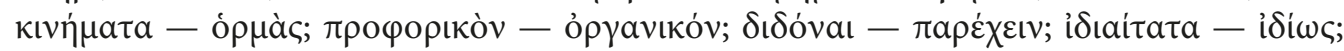

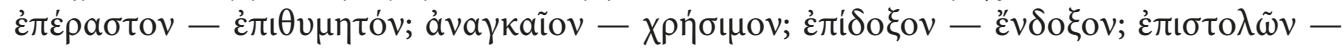
$\gamma \rho \alpha \mu \mu \alpha \dot{\tau} \omega \nu ; \chi \rho \tilde{\eta} \mu \alpha-\pi \rho \alpha \dot{\gamma} \mu \alpha$. These comments indicate that the text was also the subject of some lexical analysis. The search for synonyms was a common school exercise in the framework of the grammar course (Koukoulès 1948, 109).

Fourthly, the use of EV in the school curriculum is also evidenced by its context in Vat. gr. 1405: EV is included in the vast body of manuals on rhetoric (1-110), including The art of rhetoric of Dionysius of Halicarnassus and On poetical figures of George Choiro- 
boskos. Also the manuscript contains some grammar manuals, including Theodore Gazes' Introduction to grammar. ${ }^{7}$

\section{Characteres epistolici XL (Ch40)}

Like the two manuals discussed above, this collection of model letters was probably used at school. Its functions and place in the educational program are demonstrated, first of all, by the scholia accompanying the text in most manuscripts: all the letters are analyzed with the methods of rhetorical argumentation, in each of them various kinds of epicheiremes, ergasiai and enthymemes are indicated. The terminology of these comments obviously goes back to the treatise On invention, which the Byzantine tradition ascribed to Hermogenes of Tarsos.

It should be reminded that the treatise On invention, one of the four components of the Hermogenian Art of rhetoric, discusses in detail the theory of argumentation (Hermog. Inv. 3), which is significantly different from Aristotle's and other theories (Kennedy 1983, 86-96). When we introduce a "heading" ( $\varepsilon \varepsilon \varphi \dot{\lambda} \lambda a \iota 0 v)$, we should search for epicheiremes to support it. Epicheiremes are drawn from the circumstances (àmò $\tau \tilde{\eta} \varsigma ~ \pi \varepsilon \rho \iota \sigma \tau \dot{\alpha} \sigma \varepsilon \omega \varsigma$ ), which are divided into "person, act, manner, cause, place and time". Accordingly, six kinds of epicheiremes are distinguished: "from person", "from act", "from manner" etc. But

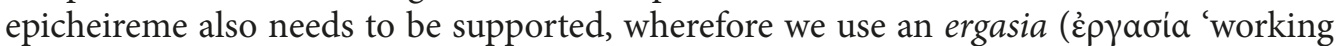
out'). Six kinds of ergasiai are distinguished: "from example" (àtò $\pi \alpha \rho a \delta \varepsilon i \gamma \mu \alpha \tau o \varsigma)$, "from

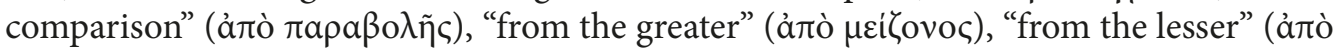

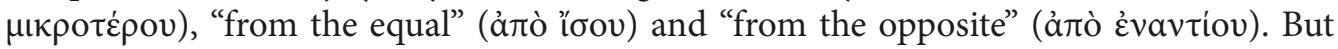
the process of argumentation doesn't end here - we need an enthymeme to support the

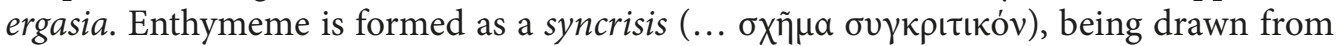
the same circumstances as an epicheirema, i.e. "from person", "from act" etc. Enthymeme can be followed by an additional enthymeme, or epenthymeme (i் $\varepsilon v \theta \dot{v} \mu \eta \mu \alpha)$.

All the terms mentioned above are presented in Cp40. Manuscripts show the importance of these remarks: if in some codices they are placed in the margins, in others they are included in the text or even turn into the subheadings of the letters' separate parts. Speaking about the meaning of these terms, we should note one important point: the authors of the scholia understand the enthymeme somewhat more broadly than (Pseudo-)Hermogenes, but rather in the way this term is interpreted in some late Byzantine textbooks and treatises - for example, in John Tzetzes' Chiliads (Leone 1968, 11. 279, 289) and in the Synopsis of rhetoric, wrongly ascribed to George Gemistos Pletho (Walz 1834, 558. 1-3, 582. 2-4). According to these texts, the enthymeme is not just an additional argument, reinforcing ergasia and having the form of a syncrisis, but a conclusion $(\sigma \nu \mu \pi \varepsilon \dot{\varepsilon} \rho \sigma \mu \alpha)$ summarizing the preceding argument. ${ }^{8}$

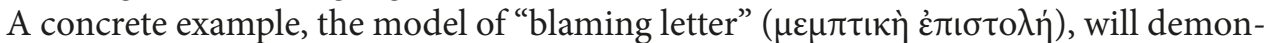
strate, how every letter is divided into different kinds of epicheiremes, ergasiai and enthymemes.

7 The description of this codex is available only in the manuscript catalogue: G. Amati. Inventarium codicum Vaticanorum Graecorum 993-2160 (Sala Cons. Mss. 323). Vaticano, 1800-1819.

8 This understanding of the enthymeme goes back to the late antique tradition, presented firstly by the so called Anonymus Seguerianus, see Patillon 2005 (text, translation and introduction). 
"Epicheireme from act. I heard that you repaid badly to those who favored you: instead of thanking them properly, you not only showed ingratitude, but also repeatedly offended them and caused them the most bitter grief that was able to reach the heart. When I found out that you acted in such an inappropriate way, I of course condemned you, I felt loathing for your wickedness and complained that you fell into madness and moved away from the right opinion. Ergasia from the lesser. And how could I not feel it, when even somebody who offended a common man is considered worthy of condemnation both by law and by the opinion of good people? How much more worthy of dishonour is one who dared to offend, or at least upset, his friends and benefactors! Enthymeme. Know that you have acted wrongly, for you not only brought condemnation on yourself, but set an evil example of offending and injuring the benefactors to many other people who will be born after you. Because of this, the Divinity will also turn against you, for you chose to be the hateful and loathsome initiator of evil deeds."

So, sample letters are analyzed with regard to the methods of rhetorical argumentation, and the basis of this analysis is the (Pseudo-)Hermogenian argumentation theory in a slightly modified form (with respect to the concept of enthymeme) - the same system that was studied in detail at the Byzantine school. Corpus hermogenianum is well known as alpha and omega of the Byzantine rhetorical theory and rhetorical education (Hunger 1978, 2:76-88; Romano 2007), and it is tempting to suggest that Ch40 was used as an appendix to the treatise On invention or to its later synopses, and the sample letters exemplified the methods of argumentation presented in them. This hypothesis is confirmed by the manuscript tradition of $\mathrm{Ch} 40$ : in two manuscripts ${ }^{9}$ the manual was copied as a direct continuation of the Pseudo-Plepho's Synopsis of rhetoric, immediately after the table of argumentation methods. In two other codices ${ }^{10} \mathrm{Ch} 40$ is provided with an introduction which briefly sums up the same theory and explains the terminology. In any case, the relationship between On invention and Ch40 can be traced quite clearly.

It should also be noted that in other manuscripts the treatise is regularly surrounded by textbooks on grammar and rhetoric. E. g. Athous Iviron 147 contains the following textbooks on grammar immediately preceding Ch40: anonymous Questions on syntax,

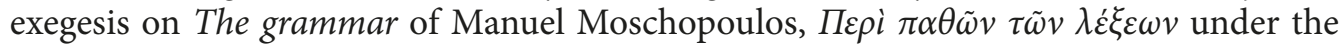

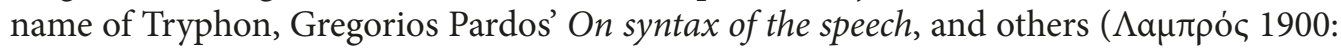
33 - 34). In another manuscript, A thous Laurae $\Omega 76$ (18 c.) PL3 constitutes a part of a collection, which includes grammatical treatises and other educational texts, e.g.: Maximos Planoudes' On verbs, On the syntax of verbs, an alphabetic list of intransitive verbs,

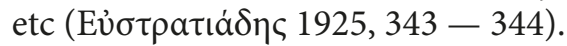

Finally, in Petropolitanus RAIK 179 (fol. 86r), the treatise has an introduction that directly testifies to its educational function:

"Epistolary style is rich and variegated, and therefore who wishes to acquire this commendable skill must learn to master this art and experience. So, if you, children, spend efforts on learning letter writing, you will get this desired grace and will be praised and honoured by all."

In the title, preserved in the published version (partly also contained in Athous Batopedi 216), it is stated that the manual will be useful "for the training of beginners"

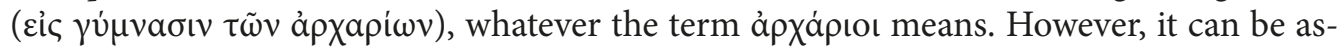

${ }^{9}$ Marcianus Cl. VIII. 12 (Mioni 1960, 138), Panormitanus 2Qq A 76 (Mioni 1965, 273-275).

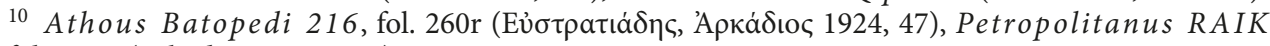
179, fol. 87r-v (Lebedeva 1973, 135) 
sumed that Ch40 was studied in school at a somewhat later stage than EV or PL1. Firstly, as an appendix to the treatise On invention it presupposed knowing its terminology, and therefore the study of these texts on the threshold of the rhetorical course would hardly be productive. Secondly, unlike EV, the content of Ch40 does not remind of school instructions, but is as close as possible to "adult" epistolary situations of real life: many of them

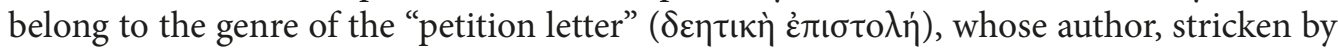
poverty and pursued by enemies, seeks protection from a powerful nobleman. Ch40 is not only a collection of abstract rhetorical exercises, but also a well of etiquette motifs and clichés, useful for writing a real letter (Chernoglazov 2018).

It is well known that in Medieval Western Europe there existed a well-developed epistolary theory, the so-called ars dictaminis. Numerous treatises on this discipline, compiled since the $11^{\text {th }}$ till the $14^{\text {th }} \mathrm{c}$., are certain to have been used as school manuals (Hartmann 2013). In Byzantine literature and educational system, it is difficult to find anything comparable with ars dictaminis in terms of scope and influence. However, as we tried to show above, the art of writing letters was probably a part of the school curriculum. If ars dictaminis was a purely medieval discipline invented in the $11^{\text {th }}$ and $12^{\text {th }} \mathrm{cc}$., and its manuals were an innovative literary phenomenon, the "conservative" Byzantium preferred textbooks that went back to antiquity; that's why the Epistolary Styles of Pseudo-Libanius and their later upgraded versions were regularly studied. These texts were used at different stages of the $\dot{\varepsilon} \gamma \kappa \dot{\kappa} \kappa \lambda \iota \varsigma, \pi \alpha \iota \delta$ sia - during the process of studying grammar and rhetoric. At the same time, samples of letters served as material for grammatical and lexical analysis (PL1 and EV) and as examples of different methods of rhetorical argumentation (Ch40). The use of PL in schools was probably the reason for its widespread popularity and extensive manuscript tradition. Beginning from the $15^{\text {th }} \mathrm{c}$. PL became well known in Western Europe, where it immediately gained authority - we know its numerous Latin translations of the $15^{\text {th }}-17^{\text {th }}$ centuries, both published and unedited. ${ }^{11}$ The treatise, adopted from the Byzantines, evidently influenced the Latin epistolary theory, but the scale of this influence remains a task for a separate study.

\section{Bibliography}

Bandini A. M. Catalogus codicum manuscriptorum Bibliothecae Medicae Laurentianae. Vol. 2. Lipsiae, Zentral-Antiquariat der Deutschen Demokratischen Republik, 1961.

Chernoglazov D.A. Die byzantinische Fassung des spätantiken Briefstellers: Überlieferung und Textgeschichte. Philologia Classica 2017, 12/2, 188-205 (cited as Chernoglazov 2017).

Chernoglazov D. A. Antichnaya epistoljarnaya teorija v Vizantii: zamechanija o neizdannom grecheskom uchebnike iz Cod. Vat. gr. 1405 [Ancient epistolary theory in Byzantium: remarks on the unpublished Greek treatise, contained in Cod. Vat. gr. 1405]. Indoevropejskoe iazykoznaniie i klassičeskaya filologija 2017, 21, 838-849 (In Russian, cited as Chernoglazov 2017a). (In Russian)

Chernoglazov D. A. Kak napisat' proshenije k vel'mozhe? Vizantijskij uchebnik po ars epistolandi i ego prakticheskaya znachimost' [How to write a petition to a grandee? Byzantine Textbook on ars epistolandi and its Practical Significance]. Indoevropejskoe iazykoznaniie I klassičeskaya filologija 2018, 22, 1329-1342. (In Russian)

Chernoglazov D., Benevich G., Choufrine A., Goncharko O., Shchukin T. Rec. Kaldellis, Siniossoglou 2017. Scrinium 2018, 14, 1-33.

Constantinides C. N. Higher education in Byzantium in the thirteenth and early fourteenth centuries (1204 ca. 1310), Nicosia, Cyprus Research Centre, 1982.

11 Early editions are enumerated and characterized in: Weichert 1910, LXX-LXXIII. 


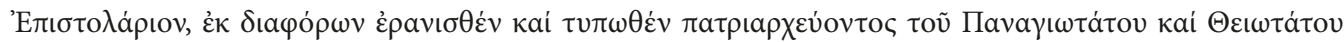

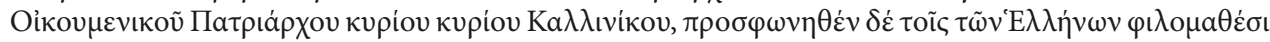

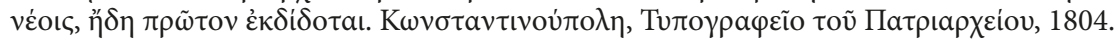

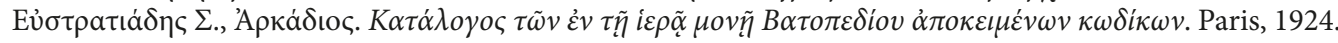

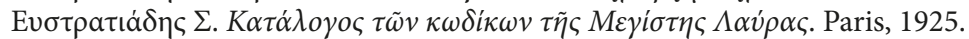

Foerster R., Richtsteig E. (eds.) Libanii Opera omnia. Vol. IX. Leipzig, Teubner, 1927.

Grünbart M. Formen der Anrede im byzantinischen Brief vom 6. bis zum 12. Jahrhundert. Wien, Verlag der Österreichischen Akademie, 2005.

Hartmann F. Ars dictaminis. Briefsteller und verbale Kommunikation in den italienischen Stadtkommunen des 11. bis 13. Jahrhunderts. Ostfildern, Thorbecke, 2013.

Hunger H. Die hochsprachliche profane Literatur der Byzantiner. Bd. 1-2. München, C. H. Beck, 1978.

Kaldellis A., Siniossoglou N.(edd.). The Cambridge Intellectual History of Byzantium. Cambridge, Cambridge University Press, 2017.

Kazhdan A.P., Epstein A.W., Change in Byzantine culture in the eleventh and twelfth centuries. Berkeley [u.a.], Univ. of California Press, 1985.

Kennedy G. A. Greek Rhetoric under Christian Emperors. Princeton, New Jersey, Princeton University Press 1983.

Koukoulès P. Vie et civilisation Byzantines. T. 1, fasc.1. Athènes, 1948.

Lambros S. P. Catalogue of the Greek Manuscripts on Mount Athos. Vol. 2. Cambridge, at the University Press, 1900.

Lemerle P. Le premier humanisme byzantin: Notes et remarques sur enseignement et culture à Byzance des origines au Xe siècle. Paris, Presses Universitaires de France 1971.

Leone P. L. M. (ed.) Ioannis Tzetzae historiae. Napoli, Libreria Scientifica Editrice 1968.

Lebedeva I.N. Opisanie Rukopisnogo otdela Biblioteki Akademii nauk SSSR, t. 5. Grecheskiie rukopisi. [Description of the Manuscript Department of the Library of the USSR Academy of Sciences, vol. 5. Greek manuscripts]. Leningrad, 1973. (In Russian)

Malherbe A. J. Ancient Epistolary Theorists. Atlanta, Scholars Press, 1988.

Martini A., Bassi D. Catalogus codicum Graecorum Bibliothecae Ambrosianae. Hildesheim, New York, Georg Olms Verlag, 1978.

Mioni E. Bibliothecae Divi Marci Venetiarum codices Graeci manuscripti. Vol.2. Roma, Istituto poligrafico dello Stato, 1960.

Mioni E. Catalogo di manoscritti greci esistenti nelle biblioteche italiane. Vol. 1. Roma, Istituto poligrafico dello Stato 1965.

Moschopulos M., Gaza Th. Grammaticae artis Graecae methodus Manuele Moschopulo authore. Eiusdem artis Theodori Gazae lib. II. Basileae, ex Officina Ioan. Vualder, 1540.

Omont H. Inventaire sommaire des manuscrits grecs de la Bibliothèque Nationale. Vol.1-3. Paris, Picard, $1886-1888$

Patillon M. (ed.) Anonyme de Séguier. Art du discours politique. Paris, Les Belles Lettres, 2005.

Rabe H. Aus Rhetoren-Handschriften: 9. Griechische Briefsteller. Rheinisches Museum für Philologie 1909, 64, 284-309.

Romano R. La teoria della retorica a Bisanzio dal tardoantico alla rinascenza macedone. Porphyra 2007, 9 , $107-125$.

Rostagno E., Festa N.Indice dei Codici greci Laurenziani non compresi nel Catalogo del Bandini. Studi italiani di Filologia classica 1893, 1, 129-232.

Stevenson H. M. Codices manuscripti Palatini Graeci Bibliothecae Vaticanae descripti. Romae, Ex Typographeo Vaticano, 1885.

Studemund W., Cohn L. Verzeichniss der griechischen Handschriften der königlichen Bibliothek zu Berlin. Berlin, A. Asher\&Co 1890.

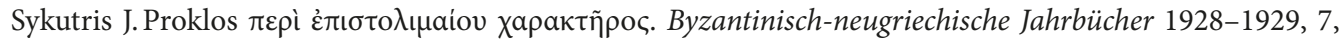
$108-118$.

Voltz L., Crönert W. Der Codex 2773 miscellaneus graecus der Grossherzoglichen Hofbibliothek zu Darmstadt. Ein Beitrag zur griech. Exzerpten-Litteratur. Centralblatt für Bibliothekwesen 1897, 14, 537-571.

Walz Ch. (ed.) Rhetores Graeci: ex codicibus Florentinis, Mediolanensibus, Monacensibus, Neapolitanis, Parisiensibus, Romanis, Venetis, Taurinensibus et Vindobonensibus. Vol. 6. Stuttgartiae, u.a. 1834.

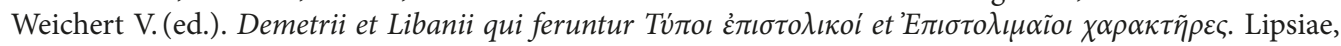
Teubner 1910. 
Zilliacus H. Untersuchungen zu den abstrakten Anredeformen und Höflichkeitstiteln im Griechischen. Helsingfors 1949.

Received: August 15, 2018

Accepted: October 20, 2018

\section{Античная эпистолярная теория в византийской школе: учебник Псевдо-Либания и его позднейшие версии}

\section{Дмитрий Александрович Черноглазов}

Санкт-Петербургский государственный университет,

Российская Федерация, 199034, Санкт-Петербург, Университетская наб., 7-9;

d.chernoglazov@spbu.ru

«Эпистолярные стили» Псевдо-Либания (сокр. PL), позднеантичное пособие по эпистолярному искусству, были хорошо известны византийцам. Текст многократно копировался, комментировался и дополнялся, на его основе создавались новые трактаты. Задача настоящей статьи - показать, что PL и его позднейшие версии использовались в Византии как школьные учебники, охарактеризовать их функцию и место в учебной

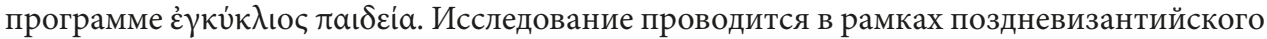
периода (XIII-XV вв.). Анализируются следующие тексты: PL в изначальной версии (PL1), Epistolarium Vaticanum - анонимная версия, известная в двух рукописях XV в. (EV), Characteres epistolici XL - собрание из 40 образцовых писем, распространенное в поздне- и поствизантийскую эпоху (Ch40). PL1 использовался, видимо, в рамках курса грамматики или как переходное звено к курсу риторики. Об этом свидетельствует его рукописная традиция - трактат зачастую копировался вместе со школьными пособиями по грамматике, риторике, а также и с другой учебной литературой. Сохранилась версия PL1 с грамматическими комментариями - свидетельство того, что он служил материалом для грамматического анализа. EV использовался на раннем этапе $\dot{\varepsilon} \gamma \kappa u ́ \kappa \lambda \iota \varsigma, \pi \alpha \iota \delta \varepsilon \dot{\alpha}$, в рамках курса грамматики. Это явствует из его содержания - образцовые письма носят сугубо дидактический характер и адресованы детям. На школьное употребление EV указывают и глоссы в рукописях. Ch40 изучался на более поздней стадии учебного процесса - в рамках курса риторики. Схолии в рукописях показывают, что текст анализировался с точки зрения приемов риторической аргументации. Терминология схолиев восходит к трактату «О нахождении», принадлежащему, возможно, Гермогену Тарсийскому. Вероятно, Ch40 служил приложением к трактату и его позднейшим синопсисам.

Ключевые слова: эпистолография, эпистолярная теория, риторическая теория, теория аргументации, грамматика, система образования, школьные учебники, Псевдо-Либа-

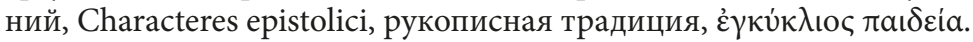

